\title{
TBI in ESP Class: The Advantages and Limitations
}

\author{
Ivonne Susan \\ Universitas Pendidikan Indonesia \\ ivonne.susan1@gmail.com
}

\begin{abstract}
English for general purposes (EGP) cannot suit in all work field, thus community realizes that English for specific purposes (ESP) is needed. As we know that ESP course is aimed to prepare the learners to execute specific task or set of tasks. Unfortunately, a research revealed that there were some problems related to a course, task assignment and teaching method. Therefore, Task Based Instructions (TBI), which carries out task or set of task, might be considered as one of suitable methods to be applied in this field. This research was conducted to uncover the advantages and limitations of implementing TBI in ESP classroom. This research was conducted in one of language center in Bandung. In order to gain comprehensive and reliable data, close-ended questionnaire, observation and interview were employed in this qualitative study. Hopefully, the finding of this research could be one of references in applying this method. Furthermore, different methodology and level of students can be considered for future study in similar research area.
\end{abstract}

Keywords: advantages, limitation, TBI, ESP.

\section{INTRODUCTION}

Because of the development of all country around the world, the need of English as one of international languages to communicate is high. There are many work fields mention English ability as one of their obligation requirements. Unfortunately, the teaching of ESP seems like it cannot reach the expectation. Andriani (2014) mentions that one of problems in teaching ESP is the teachers sometimes only ask the students to memorize terminologies in the subject field. Hence, in order to meet the students' needs, teachers should use a method and instruction that should be implemented in the class to make students not only enjoy learning the language but also meet their needs, so they can achieve the goal of the course.

This study employed a qualitative research design through a case study as a method. This study was categorized as qualitative research because of the following characteristics. First, this study investigated the process of Task-Based Instruction (TBI) that is implemented in the classroom (see Fraenkel et.al., 1993). The main focus on this study was capturing the teaching learning activities occurred in the classroom. Second, this study was intended to deeply examine the phenomena of using Task-Based Instruction in ESP classroom in natural setting (See Creswell, 2009). The present study allowed the researcher to gain an in depth understanding of particular events, a program, a process, and activity which was focused on teaching learning process, benefits, and challenges in the teaching ESP classroom by using Task-Based Instruction (see Creswell, 2009).

This research was conducted on a teacher at a Sekolah Bahasa in Bandung. Since this research seek in depth the implementation of TBI in ESP class, the selection of site and participants were seen as an important part. Selecting the sites and participants purposively helps the researcher to understand the issue and the research question (Creswell 2009). This school was chosen because of three reasons, they are: the school's curriculum, teaching method, and the access.

First, the school curriculum applies ESP in teaching learning process. This school trains army, pilots, and aircraft engineering etc to learn English. Second reason of why the research was conducted in Sekolah Bahasa Bandung was because its teaching method used by the teacher. The last was the access, since some members of the institution gave positive responses of this research, and the commander of the institution allowed the research to be done in this institution. It was assumed that the research was possible to be held in this institution. Seeking approval from the gatekeeper at the research site providing access to the sites and permitting to conduct the research is essential to get access to the research or archival sites (Creswell, 2009). Since the research was permitted in the school, a particular class was chosen based on the possibility of applying the teaching method. Since, Bruton (2005), and Swan (2005) mentioned that TBLT was unsuitable for low level learners. In this case, the smartest class was chosen to be applied with particular teaching method. A particular teacher was chosen based on his teaching ability. The teacher was professional and was trained in Australia. Pre observation and pilot study showed the teacher used TBI in conducting teaching learning process.

The population of this research was a Sekolah Bahasa in Bandung. The Sekolah Bahasa was chosen because it provided ESP as the material to be learnt by the students. The class chosen was an A class which consist of 27 students. The A class was taken because this class got the highest English proficiency level in the school. And TBI required high level proficiency of the learners. Bruton (2002), and Swan (2005) mentioned that TBLT was unsuitable for low level learners. It means that, this class was potential source for the data to provide the objective of the research.

\section{METHODS}

This research is a qualitative research; the data was gained through classroom observation, interview, and questionnaire. Observation conducted in order to gather information of how the teacher implements TBI in ESP classroom. Interview was 
conducted in order to gain deep understanding; the interview was conducted after the classroom observation. It means, in order to understand respondent, the interview should be done. Interview is utilized as directive means to seek what people are thinking, feeling, and doing (Given, 2008). Moreover, Creswell (2009) mentioned that through interview, participants are able to deliver historical information. Questionnaire was conducted to explore learners' response towards the implementation of TBI. The recent study by Weichselgartner \& Sperling (1987) and Kara (2009) mentions that questionnaire is used in order to cover all learners' perception in the classroom. The questionnaire that was used in this study was adapted from previous study conducted by Gunawan (2013).

In order to gain valid and reliable data, triangulation is applied in analyzing the data. It utilizes to compare and contrast the data which had been taken from the field through classroom observation, interview, and questionnaire. The data was analyzed by reading the whole data, coding the data, describing the data and then relating it with the theory and the last the data was described.

\section{RESULTS AND DISCUSSION}

\section{Benefits of the Implementation of Task-based Instruction in Teaching ESP}

In his study, some benefits were found during the implementation of task-based instruction. First, task-based instruction contributes to the students' speaking skill. It is related to the students' ability in interacting in English, not only with the teacher when they do question and answer, but also with other students when they doing the task. Second, task-based instruction contributes to students' participation in the classroom. Further, those benefits are in line with the statement that TBI can support the development of students' target language (Willis, 1996). These findings also correspond with the study conducted by Torky (2006) who found that Task-based instruction can give positive attitudes to learning to speak, help the students to increase their motivation to speak, and increase the students' ability to speak fluently and correctly.

\section{Task-based Instruction Enhances Students' Participation in Teaching Learning}

In task-based instruction, teacher gives opportunity for the students to explore language using target language. Therefore, it is pointed out that task-based instruction activities encourage the students to be active in teaching learning process (Nunan, 2004; Richards \& Rodgers, 2001). In other words, all students need to get involved in classroom activities.

The result of the interview and the classroom observation in this study revealed that activities done every meeting enhanced students' participation in teaching learning process.
The students-teacher dialogue in the pre-task cycle was as follows:

\section{(Excerpt 2)}

$\mathrm{T}$ : when we use modals?

$\mathrm{S}$ : when we want suggest something.

$\mathrm{T}$ : ok, when we want to suggest something. ok, after we use modals. what come after modals?

Ss : ....

$\mathrm{T}$ : ok, after we use modals, se use verb?

Ss : ....

$\mathrm{T}$ : we use verb?

Ss : verb 1

$\mathrm{T}$ : yes, after we use modals verb, we use verb 1 . give me an example! (pointing a student)

$\mathrm{S}$ : I can swim

$\mathrm{T}$ : ok, for example, I have to go to Australia by tomorrow morning, what should I do?

$\mathrm{S} 1$ : you should go by plane

S28: you should buy a ticket

S17 : you should....

$\mathrm{T}$ : ok, you should plus verb 1. remember, after use should. use verb 1. after use should, you use what?

Ss : verb 1

$\mathrm{T}$ : ok other example, I feel headache.

S14 : you should drink a medicine

S11 : you should go to the doctor

$\mathrm{S} 3$ : you should take a rest

\section{(O\#1, Obs\#1, 04/08/2015)}

Not only effects could be found in pre-task cycle, but the effect also could be found in the task-cycle when they interacted and worked in groups or in pairs.

Moreover, students' participation in the classroom could be seen from the students' questionnaires result distributed to the students. It was found, from the questionnaire, that $98.65 \%$ of the students stated that they were very active in task-based instruction lesson, while $1.35 \%$ of them stated that they were quite active in answering the questions. It was also confirmed by the statements written by the students and the teacher's statement below.

\section{(Excerpt 1)}

"Sama seperti mahasiswa lainnya, saya ikut aktif dalam pembelajaran” ( $s 5)$

(Just like any other students, I get involved actively in the classroom)

\section{(Excerpt 2)}

"Sangat antusias karena ingin mengerti dan paham"

(I feel so eager to understand and comprehend English) 
class. It mentions that the students get more knowledge in English lesson. It also illustrates that task-based instruction also enhanced his confidence in speaking.

In this context, the students not only practice how to speak using target language but also how to communicate. Based on the teacher's interview, after implementing TBI, the students were adapted in paying attention to their accuracy while performing dialog and stating the expressions orally without being hesitant. Consequently, after several meetings, it encouraged them to speak and communicate. This finding also was depicted in the data of teacher's interview which highlighted the students' speaking improvement as follow.

\section{(Excerpt 8)}

I think their speaking ability is improving. Now, they can share their opinion. I think that's an achievement for them. (Teacher's response, $27^{\text {th }}$ October 2015) questionnaires, and interview, it was found that task-based instruction contributes to students' speaking skill. It was reflected during the classroom observation. When the students voluntarily performed their dialog in front of the class at the first meeting, most of them did not really pay attention to the accuracy. After several meetings, the students became aware of the form of language. These effects can be seen in reporting stage of task cycle during performing dialog and in language form of post-task cycle where the teacher reviewed language form which helped the students to be aware of the structure of language.

Additionally, based on the questionnaires, most of the students feel that task-based instruction activities contribute to their speaking skill. It can be seen through classroom observation where the students gave their opinion freely in English. And it happened not only when the students did a conversation with the teacher but also with their group members and in front of the class. Among 27 students, $100 \%$ or 27 students stated that their speaking skill is developed through task-based instruction. Regarding this, the followings are what the students wrote in the questionnaire.

\author{
(Excerpt 5) \\ "Saya menjadi lebih terbiasa dalam mengucapkan \\ bahasa inggris" (S2) \\ (I am used to speak English) \\ (Excerpt 6) \\ "Mengalami peningkatan dan mendapat pengetahuan \\ lebih (vocabulary)” (S6) \\ (My English is improving and I get more knowledge \\ (vocabulary)) \\ (Excerpt 7) \\ "lebih berani dan percaya diri dalam berbicara" (S9) \\ (I am confident in speaking English)
}

Excerpt 5, 6, and 7 illustrate that the student speaking skill was developing because he speaks English every day in the
The teacher's statement above indicated that the activities in task-based instruction implementation determined the students' speaking. It was because the activities in TBI encouraged the students to speak actively, gave the students opportunity to learn pronunciation, vocabulary, and grammar, encouraged the students to work independently, and encouraged them to interact in English. Thus, the activities seemed motivating the students in learning. These findings may relate to the study conducted by Hadi (2013) which uncovered that the activities provided by the teacher not only encourages academic progress of the students, but also improves students' interaction skill, and motivates their learning.

Further, those benefits are in line with the statement that TBI can support the development of students' target language (Willis, 1996). These findings also correspond to the study conducted by Torky (2006) who found that Task-based instruction can give positive attitudes of learning to speak, help the students to increase their motivation to speak, and increase the students' ability to speak fluently and correctly.

\section{The limitation in implementing Task-based Instruction in Teaching ESP}

In implementing the task-based instruction, there were two main challenges that could hinder the effectiveness in gaining its benefits. The limitation had something to do with availability of time, and the number of students in the classroom.

\section{Time availability}

The first challenge found in the implementation of task-based instruction was teacher's competence. Based on the interview, the challenges during the implementation of task-based instruction it was found that in the implementation of taskbased instruction was the time of learning. In this institution, the teacher enter the class $2 \times 45$ minutes and the last 4 meeting based on the observation, the teacher was running out of time, so the he could not let all students practice in the language 
focus phase. The teacher also admitted that he could not manage the time properly.

\section{(Excerpt 9)}

Q : what are the challenges of applying TBI in your class?

A : the time, I usually got distract and talk too much. When I explain about something, I usually did not focus on the material. (Teacher's response, $27^{\text {th }}$ October 2015)

This limited time of learning also influenced to students' language learning, such as grammar and vocabulary. Based on the questionnaire above, it was also found that the student seemed need more duration of time in understanding grammar and memorizing vocabularies. The reason might because they were used to learn English which focused on word formation, spelling, and vocabulary (Alwasilah, 2001).

As a consequence, the students with better language form were able to follow the instruction. It was because they could comprehend the instruction better. Thus, this challenge should be taken into account for the teacher in managing tasks with better proportion of time.

\section{The number of students}

The second challenge found in the implementation of taskbased instruction was the number of students. In this institution, the number of students was only 15-20. Since the number of students that was accepted in the institution was increasing, so that the students in A class is more than 20 students. The teacher said that it was hard for him to monitor the classroom when the students are too many.

\section{(Excerpt 10)}

"Banyak siswanya dalam kelas (S8)"

"(There are too many students in the classroom)"

One of the students recognized that there are too many students in the classroom.

\section{(Excerpt 11)}

Q : what are challenges that you faced when you apply TBI in the class?

A : the main point is the total of students in the classroom. if the students are too many, it would be difficult for me to monitor what they're doing. (Teacher's response, $27^{\text {th }}$ October 2015)

The second excerpt indicated that the teacher took the number of students as an issue in teaching learning process. Taskbased instruction is hard to be implemented in big classroom Ellis (2003). He mentioned that it was difficult for him to be able to monitor every student's comprehension in a big classroom. In consequence of this issue, some students could not get full attention from the teacher.

\section{REFERENCES}

Alwasilah, A. C. (2001). Language, culture, and education: A portrait of contemporary Indonesia. Andira.

Andriani, G. (2014). Problems in teaching English for Specific Purposes (ESP) in higher education. NOBEL journal of literature, language and language teaching, 5(1).30-40

Bruton, A. (2005). Task-based language teaching: For the state secondary FL Classroom?. Language Learning Journal, $\quad 31 \quad$ (1), 55-68. http://doi.org/10.1080/09571730585200091

Creswell, J. W. (2009). Research design: Qualitative, quantitative, and mixed methods approaches (3rd ed.). Los Angeles: Sage Publications, Inc.

Ellis, R. (2003). Task-based language learning and teaching. Oxford University Press.

Fraenkel, J. R., Wallen, N. E, \& Hyun, H. H. (1993). How to design and evaluate research in Education. Vol. 7. New York: McGraw-Hill.

Given, L. M. (Ed.). (2008). The Sage encyclopedia of qualitative research methods. Sage Publications.

Gunawan, I. D. (2013). Penerapan model pembelajaran berbasis tugas (Task-based learning) bagi peningkatan keterampilan berbicara bahasa inggris: Studi pada mahasiswa Perguruan Tinggi di Bandung. Doctoral dissertation, Universitas Pendidikan Indonesia.

Hadijah, D. (2010). An analysis of materials and students' needs in learning English: A case study at institute of higher education in Bandung. Unpublished Doctoral dissertation, Indonesia University of Education.

Hadi, A. (2013). Perceptions of task-based language teaching: A study of Iranian EFL learners. English Language Teaching, 6(1), 103.

Kara, A. (2009). The effect of a 'learning theories' unit on students' attitudes toward learning. Australian Journal of Teacher Education, 34(3), 100-113.

Nunan, D. (2004). Task-based language teaching. New York: Cambridge.

Richards, J. C., \& Rodgers, T. S. (2001). Approaches and methods in language teaching (2nd ed.). Cambridge; New York: Cambridge University Press.

Swan, M. (2005). Legislation by hypothesis: The case of taskbased instruction. Applied Linguistics, 26(3), 376-401.

Torky, S. A. E. (2006). The Effectiveness of a Task-Based Instruction Program in Developing the English Language Speaking Skills of Secondary Stage Students. Online Submission. Retrieved from http://eric.ed.gov/?id=ED523922 
Weichselgartner, E., \& Sperling, G. (1987). Dynamics of automatic

and

controlled

visual

attention. Science, 238(4828), 778-781.
Willis, J. (1996). A framework for task-based learning. London: Longman. 